\title{
THE BENZODIAZEPINE RECEPTOR AND RECEPTOR TOLERANCE PRODUCED BY CHRONIC TREATMENT OF DIAZEPAM
}

\author{
Tetsuji HIRONAKA, Katsuhiro FUCHINO and Tomoko FUJII \\ Department of Pharmacology. Teikyo University School of Medicine. \\ Kaga 2-11-1, Itabashi-ku, Tokyo 173, Japan
}

Accepted September 10, 1982

\begin{abstract}
A characterization of the benzodiazepine receptor in vivo was carried out utilizing the up-and-down method for a quantitative determination of the maximal seizure threshold to diazepam. Wistar-Imamichi male rats of 21 days of age were used. The drug concentration in the brain at the steady-state was measured with radiolabeled diazepam. A kinetic analysis for the dose-response relation obtained gave $2.2 \mu \mathrm{M}$ and 1.6 for the $\mathrm{Kd}$ and $\mathrm{n}$, respectively, in the Langmuir adsorption isotherm. The results suggested the existence of a hitherto undiscovered endogenous ligand(s) suppressing the binding of benzodiazepine to the receptor, as compared with those in the in vitro binding-assay reported by other investigators. A chronic pretreatment with diazepam once a day for 13 days ( 0.2 and $2 \mathrm{mg} / \mathrm{kg}$, s.c.) produced receptor tolerance, but did not affect the amount of the seizure threshold unless the drug was acutely administered $10 \mathrm{~min}$ before the electric shock. These results supported the argument that two distinct entities exist for both GABA and benzodiazepine recognition sites which are closely related to each other in their functioning.
\end{abstract}

Three major actions of the benzodiazepines, anxiolytic, anticonvulsant and muscle relaxant activities, have been shown to have a good correlation with the binding ability of the drugs to the receptor $(1,2)$. By virtue of the discovery of the endorphins for the opiate receptor, one may inquire as to the possible physiological significance of the benzodiazepine receptors, and an endogenous ligand(s) for the receptor is being widely sought for a better understanding of the mechanisms underlying the drug-mediated and physiologica! effects (3-6).

Although much additional characterization of the receptor is required to establish a putative endogenous ligand for the benzodiazepine receptor as a true neurotransmitter or neuromodulator (4), the biological responses of intact neurons have been largely neglected in recent CNS pharmacology with the emergence of ligand displacement methodology (7).

In the present study, in vivo evidence for the existence of the drug receptor for diazepam was provided with its desensitizing characteristics deduced from a quantitative determination of the maximal seizure threshold. A preliminary report has appeared elsewhere (8).

\section{Materials and Methods}

Animals: Wistar-Imamichi male rats (Institute for Animal Reproduction, Ohmiya) were used at 21 days of age when ontogenetic development of the benzodiazepine receptor is virtually complete $(9,10)$. ED50 was determined on groups of 8 to 10 rats, which were formed from the large number of animals from the same farm necessary for one experiment and randomized for body weight 
and their mothers fed. The mother rats were maintained on a laboratory chow (Oriental Yeast Co., Ltd.) and tap water ad libitum and were kept in a temperature-controlled room $\left(22 \pm 3^{\circ} \mathrm{C}\right)$ with a lighting schedule of $14 \mathrm{hr}$ light (06:00-20:00) and 10 hr darkness.

Chemicals: Diazepam was dissolved in a $5 \%$ ethanol solution so as to give a constant volume $(0.02 \mathrm{ml} / \mathrm{g}$ body weight) and administered intraperitoneally $10 \mathrm{~min}$ before electric shock. For chronic treatment, the drug was given subcutaneously once a day for 13 days from the 8th to the 20th day after birth.

Measurement of seizure threshold: The maximal seizure threshold (MST) was adopted as a criterion, and the up-and-down method was utilized to determine the precise seizure threshold $\left(\mathrm{MST}_{50}\right)$. The details of the measurement are described in the previous study (11).

Measurement of serum calcium concentration: Immediately after judging the all-ornone type of seizure response, the animal was bled by cutting the juglar vein. The serum was treated with Lanthanum-TCA solution and centrifuged at $3,000 \times \mathrm{g}$ for $10 \mathrm{~min}$. The supernatant was then used for atomic absorption analysis for determining the calcium concentration in the serum.

Measurement of radioactivity: Onehundred $\mu \mathrm{Ci}$ of $\left[\mathrm{N}\right.$-methyl- $\left.{ }^{3} \mathrm{H}\right]$-diazepam (specific activity of $97 \mathrm{Ci} / \mathrm{mmol}$. Amersham) was mixed with $0.9 \mathrm{mg}$ of unlabeled diazepam (Takeda) and dissolved in $20 \mathrm{ml}$ of $5 \%$ ethanol solution. The drug was administered intraperitoneally so as to make a constant volume ( $0.02 \mathrm{ml} / \mathrm{g}$ body weight). Blood samples were taken by decapitation and prevented from coagulation by adding $10 \mathrm{U}$ of heparin. One hundred $\mu$ of whole blood was solubilized with $2 \mathrm{ml}$ of NCS and decolorized with $1 \mathrm{ml}$ of the benzoyl peroxide solution. Finally, $10 \mathrm{ml}$ of PCS (Amersham) scintillator solution was added for radioactivity determination.
Brain samples were dissected superficially to weigh about $50 \mathrm{mg}$ for each region (cerebral cortex, hippocampus, cerebeliar cortex and medulla) and washed out quickly for possible bleeding with physiological solution. The NCS solubilizer and PCS scintillator solutions were also used for the brain samples. The radioactivity counts were calibrated for the drug concentration by the preparative standard.

In the present study, the radioactivities measured at $10 \mathrm{~min}$ after intraperitoneal administration were approximated to be diazepam since no significant amount of the metabolites were expected to appear by that time based on the other experimental data in rats $(12,13)$.

\section{Results}

Diazepam concentrations in blood and brain after intraperitoneal administration: To establish the experimental conditions under which the steady-state pharmacokinetics of diazepam could be obtained, the time course of absorption and distribution of the drug were examined. After intraperitoneal injection of $0.9 \mathrm{mg} / \mathrm{kg}$ of diazepam with a tracer amount of radioactivity. samples of blood and brain tissues were taken from each animal at various time intervals.

Diazepam was absorbed very rapidly, and its concentration in the blood reached a peak in $10 \mathrm{~min}$ (Fig. 1A). The average concentration at $10 \mathrm{~min}$ was $0.45 \pm 0.02 \mu \mathrm{g} / \mathrm{ml}$ (mean \pm S.E., $n=4$ ). Transfer of the drug from the blood to the brain was also very rapid. and already at 2 min after injection, an even higher concentration was attained in the brain than in the blood. The drug concentration in the brain became maximal in $6 \mathrm{~min}$ and this level continued for several min. The overall average concentration in the brain at $10 \mathrm{~min}$ was $0.70 \pm 0.053 \mu \mathrm{g} / \mathrm{g}$ tissue (mean \pm S.E.M., $n=4)$, which was $56 \%$ higher than that in the blood, suggesting a high affinity 

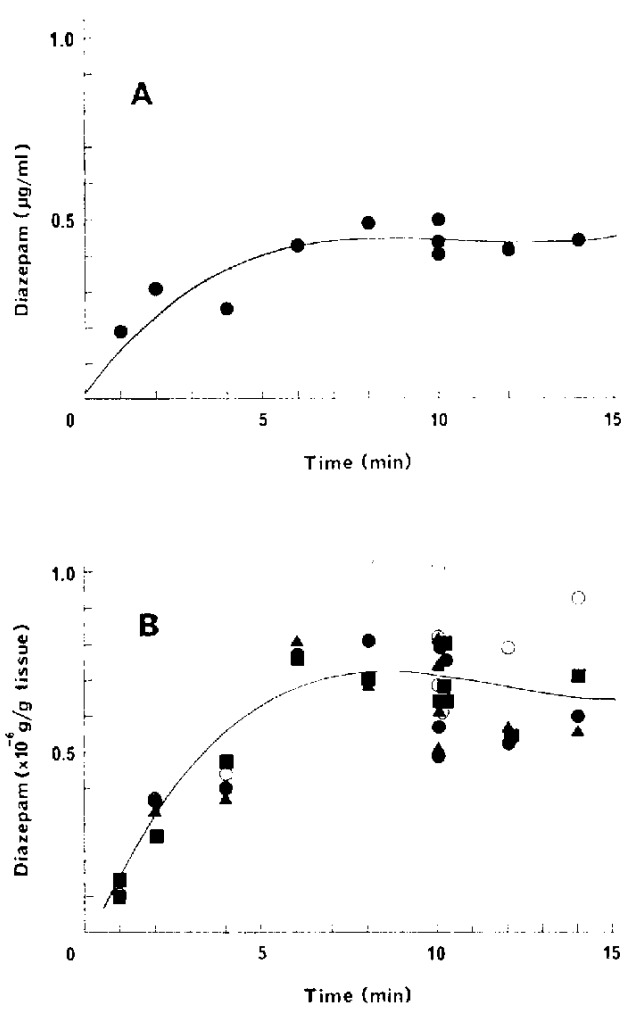

Fig. 1. Time course of absorption and distribution of diazepam after intraperitoneal administration. The drug dissolved in $5 \%$ ethanol solution $10.9 \mathrm{mg} /$ $\mathrm{kg}$ ) was given with a tracer amount of [ $N$-methyl$\mathrm{H}^{3}$ ] diazepam. Ordinate: diazepam concentration in $\mu \mathrm{g} / \mathrm{ml}$ or $\mathrm{g}$ tissue. Abscissa: time after injection in min. A, blood: B, brain tissue in which the filled squares are for the cerebral cortex; filled circles, the hyppocampus; filled triangles, the cerebellar cortex; and open circles. the medullary region. The solid curve, a third power of polynomial regression. Each point represents the value from one animal.

of the drug for the brain tissues (Fig. 1A, B). Based on the result shown in Fig. 1, a $10 \mathrm{~min}$ wait after the drug administration was chosen in the following electric shock experiments for the steady-state pharmacokinetic analysis.

The dose-response relationship for anticonvulsant effect of diazepam: The $\mathrm{MST}_{50}$ for the control rats (solvent alone) was $32.6 \pm 0.18 \quad(n=4) \mathrm{mA}$ with little variation among the groups. The $\mathrm{MST}_{50}$ was elevated with an increase in the drug dose in a dose-

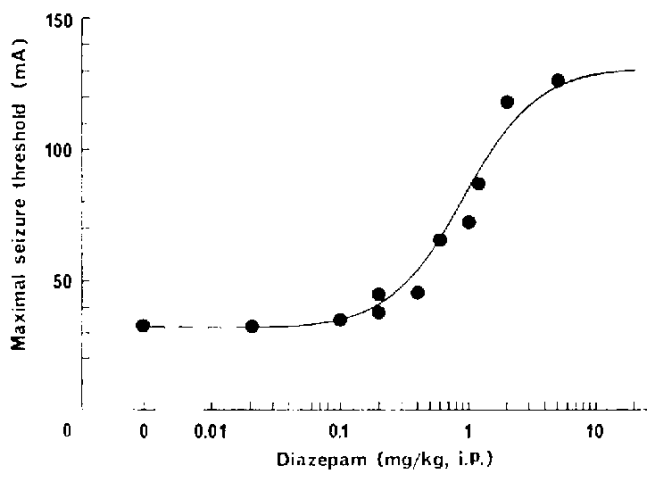

Fig. 2. A dose-response relationship for the anticonvulsant effect of diazepam. Ordinate: the maximal seizure threshold as determined by the "up-anddown method" in mA. Abscissa: logarithm of the intraperitoneally administered drug dose, except zero. Each point was obtained from 8 to 10 rats. The solid curve was drawn according to Eq. 1, where $\mathrm{Kd}$ and $\mathrm{n}$ values were obtained by the least squares method as described in the text. $K d, 0.86$ $\mathrm{mg} / \mathrm{kg}: \mathrm{n} .1 .55$.

dependent manner, and a sigmoid curve was attained in the dose-response relation (Fig. 2).

When diazepam was given beyond the maximum dose used in Fig. 2, the tonic convulsion that was a necessary sign for the maximal seizure was abolished to any large seizure current. When rats were given physiological solution alone, the $\mathrm{MST}_{50}$ was 28.3 $\mathrm{mA}$. These results indicate that the $5 \%$ ethanol solution $(0.1 \%$ in the body weight) elevated the seizure threshold by $4.3 \mathrm{~mA}$. which was $15 \%$ of the control.

Assuming that diazepam combines with the benzodiazepine receptor in a manner expressed by the Langmuir adsorption isotherm and that the elevation of the $\mathrm{MST}_{50}$ is somehow proportional to the number of receptors occupied by the drug:

$$
\begin{aligned}
& \text { Receptor }+n \text { (diazepam) } \rightleftharpoons \\
& \quad \text { (diazepam })_{n} \text { (Receptor) }
\end{aligned}
$$

where $\mathrm{n}$ is the number of the drug molecules At equilibrium.

$$
Y=\frac{R_{\max }+R_{\min } \cdot K d / D^{n}}{1+K d / D^{n}}
$$


where $R_{\max }$ designates the maximum response; $R_{\min }$, the minimum response; and $D$, the concentration of the drug. By arranging Eq. 1 , the $\mathrm{Kd}$ and $\mathrm{n}$ values were obtained by the least squares method from the intercept and the slope, respectively. The solid curve in Fig. 2 gave the best fit for the data with values of $0.9 \mathrm{mg} / \mathrm{kg}$ and 1.6 for $\mathrm{Kd}$ and $\mathrm{n}$, respectively. The $K d$ value corrected for the brain concentration of the drug as obtained in Fig. 1 was $2.2 \mu \mathrm{M}$.

Receptor tolerance induced by chronic pretreatment of diazepam: Diazepam dissolved in a 5\% ethanol solution was chronically administered to test rats $(0.2$ and $2 \mathrm{mg} / \mathrm{kg}$, s.c.) once a day for 13 days from the 8 th to the 20th day after birth, and the thereby-produced changes in the seizure responses were examined on the $21 \mathrm{st}$ day for the pretreated rats in Fig. 3. When diazepam was acutely given to the pretreated rats, the $\mathrm{MST}_{50}$ was greatly suppressed in a manner dependent upon the dose of the pretreatment $(1,0 ; 2,0.2 ; 3,2 \mathrm{mg} / \mathrm{kg})$. In contrast. when the solvent alone was given acutely, the MST50 was not altered significantly for each group (1.2 and 3) compared to the untreated control (not shown).

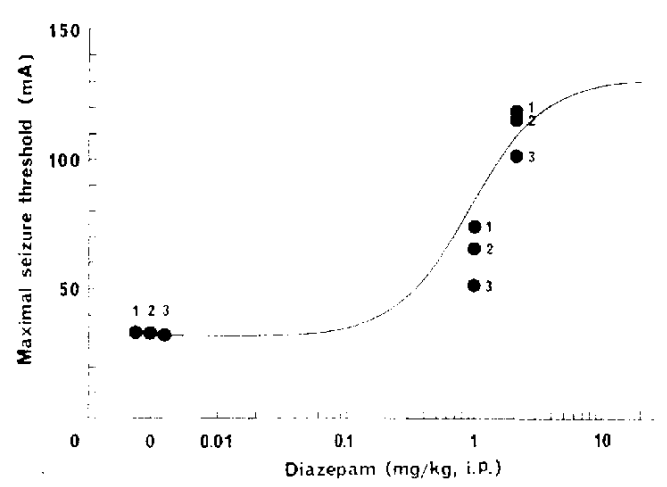

Fig. 3. Receptor tolerance induced by chronic pretreatment with diazepam. Pretreatment: 1, 5\% ethanol: 2. $0.2 \mathrm{mg} / \mathrm{kg}$ diazepam: $3.2 \mathrm{mg} / \mathrm{kg}$ diazepam. Ordinate: the MST50 in MA. Abscissa: logarithm of the acutely administered diazepam. Each point was derived from 8 to 10 rats. The solid curve was the same as that obtained in Fig. 2.
Namely, the physiological function of the relevant neurons including synaptic events was not affected by the chronic treatment, but the drug-mediated function was largely affected in terms of epileptogenic activity. These experimental facts strongly supported the argument that there exist two distinct entities for both GABA and benzodiazepine recognition sites which are closely related or are part of the same macromolecular complex (5. 14).

The drug tolerance as revealed in Fig. 3 is probably a "receptor" tolerance rather than a "metabolic" tolerance since the latter type of phenomenon is found not to occur in the 10 min after the drug administration the time, at which the seizure threshold was determined $(13,15,16)$. There is another possibility that some metabolites derived from the pretreatment behaved antagonistically to acutely administered diazepam, taking into account the relatively long biological half lives of the drug and its metabolite(s) (13. 15. 16). This possibility was, however, excluded by the experiment described below.

No residual effect of diazepam and its metabolites on the maximal seizure threshold: Three groups of rats were used, and diazepam was administered subcutaneously to each group of rats once a day for 1,2 and 3 days before the electric shock at the 21 st day after birth. None of these pretreatments exerted any influence on the MST $_{50}$ determined where $0.8 \mathrm{mg} / \mathrm{kg}$ diazepam was acutely given (Fig. 4). The result also demonstrated that the receptor tolerance was a relatively slow process that required at least 3 days for induction.

No significant alteration in serum calcium concentration by diazepam: Since an increase in serum calcium concentration raises the maximal seizure threshold (11), a possible change in the calcium concentration by diazepam was explored. However, the serum calcium concentration had not been altered 


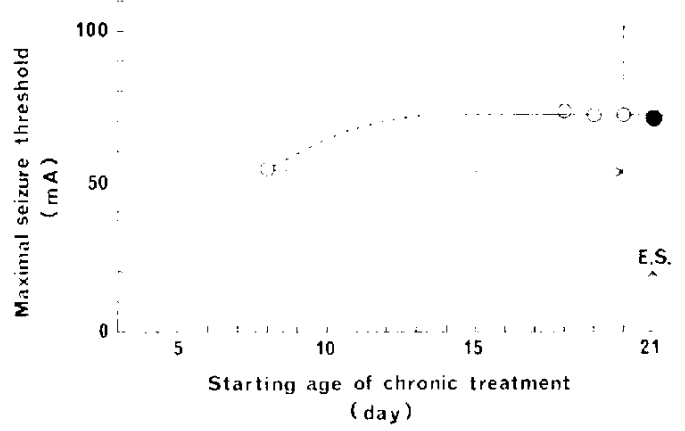

Fig. 4. The maximal seizure threshold after a short term (1-3 davs) pretreatment with diazepam. The drug at $2 \mathrm{mg} / \mathrm{kg}$ was subcutaneously given once a day as in Fig. 3. starting at the day shown on the abscissa, and the MST 50 in mA was measured at the 21 st day (arrow) on the pretreated rats to the acutely-given diazepam of $0.8 \mathrm{mg} / \mathrm{kg}$. Filled circle. with no chronic pretreatment. Each value shows the ED50 for the maximal seizure threshold obtained from 8-10 animals.

significantly by the pretreatment at the 21 st day when the receptor tolerance was produced. A short term pretreatment for 1.2 and 3 days as in Fig. 4 also did not change the serum calcium concentration at the 21 st day. When diazepam ( $2 \mathrm{mg} / \mathrm{kg}$ ) was given for 6 days from the 8 th to the 14 th day after birth, no significant change in the serum calcium concentration was observed. All these results were summarized in Table 1. Calcium ions could not be causally related to the receptor tolerance observed in Fig. 3 .

\section{Discussion}

After intraperitoneal administration, diazepam was absorbed very rapidly so as to be transfered from the blood to the brain, and it nearly attained a steady-state concentration between 6 and $12 \mathrm{~min}$ after the injection (Fig. 1). The maximal seizure threshold was quantitatively determined utilizing the "upand-down method" in its steady-state (10 min after administration), and the sigmoid curve in the dose-response relation was obtained for anti-convulsant effect of
Table 1. Serum calcium concentrations after diazepam administration

\begin{tabular}{|c|c|c|}
\hline Treatment & $\begin{array}{l}\text { Periods } \\
\text { (day) }\end{array}$ & $\begin{array}{c}\text { Serum calcium } \\
\text { concentration } \\
(\mathrm{mg} / \mathrm{dl})\end{array}$ \\
\hline Saline & $8-20$ & $\begin{array}{c}11.4 \pm 0.31 \\
n=8\end{array}$ \\
\hline $5 \%$ ethanol & $8-20$ & $\begin{array}{c}11.1 \pm 0.26 \\
n=4\end{array}$ \\
\hline \multicolumn{3}{|l|}{ Diazepam } \\
\hline $0.2 \mathrm{mg} / \mathrm{kg}$ & $8-20$ & $\begin{array}{c}11.0 \pm 0.38 \\
n=4\end{array}$ \\
\hline $2.0 \mathrm{mg} / \mathrm{kg}$ & $8-20$ & $\begin{array}{r}11.6 \pm 0.17 \\
n=13\end{array}$ \\
\hline Saline & $19-20$ & $\begin{array}{c}11.7 \pm 0.20 \\
n=6\end{array}$ \\
\hline $5 \%$ ethanol & $19-20$ & $\begin{array}{c}11.2 \pm 0.09 \\
n=7\end{array}$ \\
\hline \multicolumn{3}{|l|}{ Diazepam } \\
\hline $0.2 \mathrm{mg} / \mathrm{kg}$ & $19-20$ & $\begin{array}{c}11.4 \pm 0.31 \\
n=6\end{array}$ \\
\hline $2.0 \mathrm{mg} / \mathrm{kg}$ & $17-20$ & $\begin{array}{c}10.8 \pm 0.23 \\
n=7\end{array}$ \\
\hline${ }^{*} 5 \%$ ethanol & $8-14$ & $\begin{array}{r}11.1 \pm 0.23 \\
n=10\end{array}$ \\
\hline \multicolumn{3}{|l|}{ *Diazepam } \\
\hline $2.0 \mathrm{mg} / \mathrm{kg}$ & $8-14$ & $\begin{array}{r}11.4 \pm 0.22 \\
n=10\end{array}$ \\
\hline
\end{tabular}

Diazepam was given subcutaneously once a day for each period shown, and the serum calcium concentrations were determined at the $21 \mathrm{st}$ day except the cases indicated with an asterisk

(*) which were measured at the 15 th day.

diazepam as shown in Fig. 2.

It should be noted that the ED50 so far determined for the anti-convulsant effect of a drug was rather arbitary as can be seen in Fig. 2. In other words, there exist a number of ED50 values depending on the amount of seizure current given, which was empirically determined.

The apparent $\mathrm{Kd}$ value estimated from the dose-response curve in Fig. 2 was $2.2 \mu \mathrm{M}$. which was strikingly larger than that obtained in the binding-assay in vitro (1,2). A lower temperature used in the binding-assay may explain the 5 fold difference in binding affinity of the benzodiazepine receptor (17), though there still remains a 200 fold difference 
in the $\mathrm{Kd}$ values between the two, strongly suggesting the existence of a hitherto undiscovered endogenous ligand(s) suppressing the binding of benzodiazepine to the receptor.

The binding-assay in vitro demonstrated a single binding site for the benzodiazepine receptor in the kinetic analysis, i.e., $n=1$ in Eq. 1 (1, 2). In the present in vivo study, however, a larger value than unity for the $n$ in Eq. 1. 1.6. was obtained. This may suggest a possibility that part of the receptors has multiple binding sites. In this connection, it is noteworthy that a heterogeneity of benzodiazepine receptors has repeatedly been reported (18-23). There is another possibility that a full pharmacological response was expressed by a small precentage of the receptors occupied or a significant response was initialized after a considerable amount of receptor occupancy by the drug. The solid lines ( $A$ and $B$ ) in Fig. 5 illustrate presumed dose-response relations for these two cases

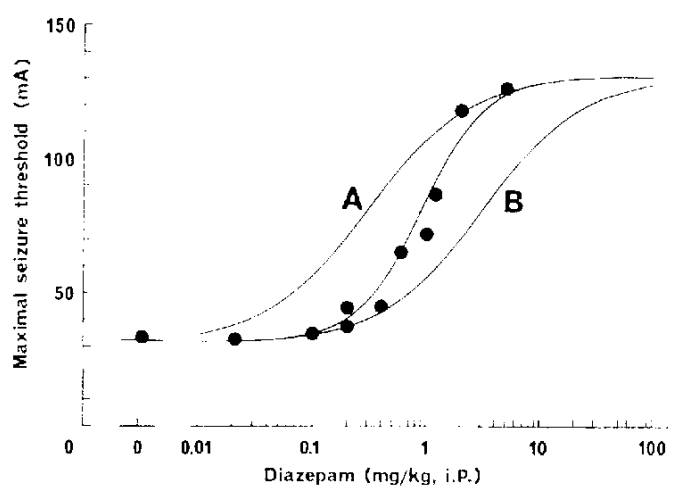

Fig. 5. A simulation of the dose-response relations for the presumed two cases of $n=1$ in Eq. 1 . The solid curve is the same as that in Fig. 2. A, for the case of a full pharmacological response produced by unsaturated receptors; $B$, for the case of initiation of a significant pharmacological response after a considerable amount of receptor occupancy. See text for the details of calculation. The dose-response relations were shifted along the dose axis as to cross the second (A) and 9th (B) points in Fig. 2. Which resulted in a rather arbitrary treatment of the data, but it was still useful to estimate a possible range for the potency of the presumed endogenous inhibitor(s). in which $\mathrm{n}$ was assumed to be unity, and the doses were calculated as to give the corresponding responses obtained in the experiment (Fig. 2). The $\mathrm{Kd}$ values estimated were $11 \mu \mathrm{M}$ and $1.1 \mu \mathrm{M}$, respectively. Therefore. the presumed endogenous ligand(s) would have a potency for suppressing the benzodiazepine receptor by a factor of 70 to 600 times. This information may be helpful for a further search for the endogenous ligand(s).

Another interesting finding in the present study was the receptor tolerance induced by chronic treatment with diazepam. In the previous study, a build-up of tolerance for benzodiazepines was suggested on epileptic seizures in Papio papio on a rather qualitative basis (24). The data reported so far in the in vitro binding-assay are not unequivocal and rather confusing (6): After long-term treatment with benzodiazepines, no changes were found with moderate or high doses $(25,26)$; other authors reported a decrease of the benzodiazepine receptor density with very high doses (27). It is unlikely that the receptor tolerance was produced by an increase in calcium concentration, leading to a stabilization of the excitable membranes (28), since neither acute nor chranic administration of diazepam produced any significant change in the serum calcium concentration (Table 1).

A consistent accumulation of demethylated metabolites in the white matter structures and in subcortical areas following a repeated administration was discussed for the mechanism of action of diazepam in the course of chronic treatment in man (29). None of the metabolites of diazepam, however, could be a deceptive cause for the receptor tolerance observed in the present study (Fig. 3) as shown in Fig. 4. It is not known whether or not any metabolite of the drug is causally implicated in the occurrence of the receptor tolerance.

The effect of the receptor tolerance was not manifested on the seizure threshold 
unless diazepam was present (Fig. 3). If this effect were on the GABAergic postsynaptic receptor. the seizure threshold should have been altered in Fig. 3 since the GABAergic synapses must be functioning during the maximal seizure (30). Thus the receptor tolerance in Fig. 3 provided in vivo evidence for the existence of its own receptor for benzodiazepine.

\section{References}

1) Squires, R.F. and Braestrup, G.: Benzodiazepine receptors in rat brain. Nature 266, 732-734 (1977)

2) Möhler, H. and Okada, T.: Benzodiazepine receptor: demonstration in the central nervous system. Science 198, 849-851 (1977)

3) Iversen, L.: Anti-anxiety receptors in the brain. Nature 266, 678 (1977)

4) Marangos, P.J., Paul, S.M., Goodwin, F.K. and Skolnick, P.: Putative endogenous ligands for the benzodiazepine receptor. Life Sci. 25 , 1093-1102 (1979)

5) Costa, E. and Guidotti, A.: Molecular mechanisms in the receptor action of benzodiazepines. Ann. Rev. Pharmacol. Toxicol. 19, 531-545 (1979)

6) Müller, W.E.: The benzodiazepine receptor. Pharmacol. 22, 153-161 (1981)

7) Bloom, F.E., Siggins, G.R. and Henriksen, S.J.: Electrophysiologic assessment of receptor changes following chronic drug treatment. Fed. Proc, 40, 166-172 (1981)

8) Fuchino, K., Hironaka, T. and Fujii, T.: Alterations in the central nervous system induced by chronic administration of diazepam during an early postnatal period in rats. Japan. J. Pharmacol. 31, Supp. 280P (1981)

9) Massotti, M., Alleva, F.R., Balazs, T. and Guidotti, A.: GABA and benzodiazepine re. ceptors in the offspring of dams receiving diazepam: ontogenic studies. Neuropharmacology 19, 951-956 (1980)

10) Regan, J.W., Roeske, W.R. and Yamamura, H.I.: The benzodiazepine receptor: its development and its modulation by $\gamma$-aminobutyric acid. J. Pharmacol. Exp. Ther. 212, 137-143 (1980)

11) Hironaka, T., Ohtaki, Y., Nakanishi, H., Morimoto, S. and Fujii, T.: Elevation of the maximal seizure threshold produced by calcium hydroxide in rats. Japan. J. Pharmacol. 31, 227$235(1981)$
12) Nau, H. and Liddiard, C.: Postnatal development of sex dependent differences in the metabolism of diazepam by rat liver. Biochem. Pharmacol. 29, 447-449 (1980)

13) Schwartz, M.A., Koechlin, B.A., Postma, E., Palmer, S. and Krol, G.: Metabolism of diazepam in rat, dog. and man. J. Pharmacol. Exp. Ther. 149, 423-435 (1965)

14) Gavish, M. and Snyder, S.H.: $\gamma$-Aminobutyric acid and benzo-diazepine receptors: copurification and characterization. Proc. Natl. Acad. Sci. U.S.A. 78, 1939-1942 (1981)

15) Van Der Kleijn, E.: Kinetics of distribution and metabolism of diazepam and chlordiazepoxide in mice. Arch. Int. Pharmacodyn. Ther. 178, 193-215 (1969)

16) Morselli, P.L., Cassano, G.B., Placidi, G.F., Muscettola, G.B. and Rizzo, M.: Kinetics of the distribution of ${ }^{14} \mathrm{C}$-diazepam and its metabolites in various areas of cat brain. In The Benzodiazepines, Edited by Garattini, S.. Mussini, E. and Randall, L.O., p. 129-143, Raven Press, New York (1973)

17) Möhler, H. and Okada, T.: Properties of ${ }^{3} \mathrm{H}$ diazepam binding to benzodiazepine receptors in rat cerebral cortex. Life Sci. 20, 2101-2110 (1977)

18) Klepner, C.A., Lippa, A.S., Benson, D.I., Sano, M.C. and Beer, B.: Resolution of two biochemically and pharmacologically distinct benzodiazepine receptors. Pharmacol. Biochem. Behav. 11, 457-462 (1979)

19) Supavilai, P. and Karobath, M.: Heterogeneity of benzodiazepine receptors in rat cerebellum and hippocampus. Eur. J. Pharmacol. 64, 9193 (1980)

20) Sieghart, $W$. and Karobath, M.: Molecular heterogeneity of benzodiazepine receptors. Nature 286, 285-287 (1980)

21) McCarthy, K.D. and Harden, T.K.: Identification of two benzodiazepine binding sites on cells cultured from rat cerebral cortex. J. Pharmacol. Exp. Ther. 216, 183-191 (1981)

22) Young. W.S., 111, Niehoff, D., Kuhar, M.J., Berr, B. and Lippa, A.S.: Multiple benzodiazepine receptor localization by light microscope radiohistochemistry. J. Pharmacol. Exp. Ther. 216, 425-430 (1981)

23) Ehlert, F.J., Roeske, W.R. and Yamamura, H.I.: Multiple benzodiazepine receptors and their regulation by $\gamma$-aminobutyric acid. Life Sci. 29, 235-248(1981)

24) Killam, E.K., Matsuzaki, M. and Killam, K.F.: Effects of chronic administration of benzodiazepines on epileptic seizures and brain electrical activity in Papio papio. In The Benzodiazepines. 
Edited by Garattini. S., Mussini. E. and Randall, L.O., P. 443-461. Raven Press. New York (1973)

25) Möhler, H. and Okada, T. and Enna, S.J.: Benzodiazepine and neurotransmitter receptor binding in rat brain after chronic administration of diazepam or phenobarbital. Brain Res. 156. $391-395$ (1978)

26) Braestrup, C., Nielsen, M. and Squires, R.F.: No changes in rat benzodiazepine receptors after withdrawal from continuous treatment with lorazepam and diazopam. Life Sci. 24, $347-350(1979)$

27) Rosenberg, H.C. and Chiu, T.H.: Docroasod ${ }^{3} \mathrm{H}$ diazepam binding is a specific response to chronic benzodiazepine treatment. Life Sci. 24, 803-808 (1979)

28) Hironaka, T. and Morimoto, S.: Computer analyses of the excitable membrane. Comput. Biomed. Res. 13, 36-51 (1980)

29) Placidi, G.F., Tognoni, G., Pacifici, G.M., Cassano, G.B. and Morselli, P.L.: Regional distribution of diazepam and its metabolites in the brain of cat aftor chronic treatment. Psychopharmacology (Berlin) 48, 133-137 (1976)

30) Zakusov, V.V., Ostrouskaya, R.U., Markovitch, V.V., Molodavkin, G.M. and Bulayev, V.M.: Electrophysiological evidence for an inhibitory action of diazepam upon cat brain cortex. Arch. int. Pharmacodyr. Ther. 214, 188-205 (1975) 